Original Paper http://ajol.info/index.php/ijbcs http://indexmedicus.afro.who.int

\title{
Nutritional composition and bioavailability prediction calcium, iron, zinc and magnesium in Justicia galeopsis leaves in Côte d'Ivoire
}

\author{
Ahou Léticia LOUKOU*, Koutoua Yves Blanchard ANVOH, Koua Hervé KOUAKOU \\ and Kouakou BROU \\ Food Science and Technology Department, Nangui Abrogoua University, Abidjan 02 BP 801 Abidjan 02, \\ Côte d'Tvoire. \\ *Corresponding author; E-mail: loukouletine@yahoo.fr; Tel: +22507739990.
}

\begin{abstract}
Wild edible plants are known to make important contributions to the livelihoods of local communities of sub-Saharan Africa countries including Côte d'Ivoire. Some have an important nutritional intake. The aim of this study was to assess the physicochemical and nutritive properties of Justicia galeopsis leaves to ascertain its nutritional suitability as well as health benefits. J. galeopsis leaves were purchased at market in Abengougou Division. Physicochemical composition, micronutrients and antinutritional factors were determined. All results, based on dry matter, had indicated that J. galeopsis leaves were very rich in fiber (33.85\%), protein $(21.11 \%)$, vitamin B12 (4173.09 $\mathrm{mg} / \mathrm{kg})$ and vitamin C $(892.17 \mathrm{mg} / \mathrm{kg}$ of fresh leaf) but low in fat (4.06\%). The mineral elements contents were high (17.76\%) with remarkable amount of potassium (103.08 g/kg), phosphorus $(77.66$ $\mathrm{g} / \mathrm{kg})$, calcium $(59.87 \mathrm{~g} / \mathrm{kg})$, sodium $(28.30 \mathrm{~g} / \mathrm{kg})$, iron $(373.01 \mathrm{mg} / \mathrm{kg})$, zinc $(177.84 \mathrm{mg} / \mathrm{kg})$ and manganese $(128.57 \mathrm{mg} / \mathrm{kg})$. The presence of phytate $(33.83 \mathrm{mg} / 100 \mathrm{~g})$, oxalate $(740.67 \mathrm{mg} / 100 \mathrm{~g})$ and tannin $(66.33$ $\mathrm{mg} / 100 \mathrm{~g})$ were revealed. The molar ratios of [Phytate]/[Ca] $(0.00),[$ Phytate]/[Zn] $(0.15),[$ Phytate]/[Fe] $(0.11)$ and $[$ Oxalate $] /[(\mathrm{Ca}+\mathrm{Mg})](0.07)$ indicate the high bioavailability for these minerals. This work revealed that $J$. galeopsis leaves are very nutritive. They could help cover people's nutritional needs and contribute to food security.

(C) 2018 International Formulae Group. All rights reserved.
\end{abstract}

Keywords: Wild edible plants, Justicia galeopsis leaves, Abengourou Division, nutritional composition, antinutritional factors, mineral bioavailability.

\section{INTRODUCTION}

Côte d'Ivoire has a genetical diversity of plant and this flora contains many wilds food plants (Djaha and Gnahoua, 2014). These wild food plants are real sources of dietary supplements and incomes in rural areas (Kouamé et al., 2008). According to Djaha and Gnahoua (2014), these plants contribute effectively to nutrition as an integral part of the diet and / or asset of family food security. They are the subject of flourishing trade whose main actors are women (Betti et al. 2016). Indeed, these plants are valuable sources of nutrients, especially, in rural areas where they contribute substantially to the intake of proteins, 
minerals, vitamins, fiber and other nutrients, which are usually rare in daily diet (Idoko et al., 2014).

Despite their importance in some local food systems, wild food plants are increasingly neglected because of the adoption of Western eating habits. In Côte d'Ivoire, for some populations, consuming these plants is a sign of poverty. In contrary, the consumption of the manufactured products is a sign of ease and social success (Kouakou, 2015). The valorization of wild food plants becomes essential to remove all prejudices.

Studies of the valorization of wild food plants were initiated to inventory them through ethnobotanical surveys and then to evaluate and show the nutritional potential of some of them. So, Justicia galeopsis $\mathrm{T}$. Anderson ex C.B. Clarke leaves has been discovered by Yao et al. (2014). For these authors, this plant seems endemic to Abengougou Division in the East of Côte d'Ivoire and is very little known in other parts of the country. They have also exhibited mainly its medicinal purpose and its high amount of total phenolics. A consumption survey realized later by Loukou et al. (2018) in this Division has shown that all the population of this region had already consumed Justicia galeopsis leaves for their flavor. The consumption of its leaves in sauce was also mentioned by Yao et al. (2014). However, the literature does not mention nutritional value of the leaves of this species which is necessary to increase the levels of consumption already too low.

The aim of this work was to assess the physicochemical and nutritive properties of Justicia galeopsis leaves in order to ascertain its nutritional suitability as well as health benefits.

\section{MATERIALS AND METHODS Sampling}

Justicia galeopsis leaves, commonly known in the local language "Agni" as Assiaploua were purchased at market in Abengougou Division. Random selection of leaves was done by purchasing from randomly selected sellers in the market. Abengougou is a Division of Côte d'Ivoire located in the eastern part of this country, between $5^{\circ} 45 \mathrm{~N}$ and $7^{\circ} 10 \mathrm{~N}$ latitudes and $3^{\circ} 10 \mathrm{~W}$ and $3^{\circ} 50 \mathrm{~W}$ longitudes (Aka et al., 2013). Plants were identified and authenticated by National Floristic Center (University Felix HouphouëtBoigny, Abidjan-Côte d'Ivoire). The collected plants (300 g) were destalked, washed with distilled water, drained at ambient temperature and oven-dried (Memmert, Germany) at $60{ }^{\circ} \mathrm{C}$ for $72 \mathrm{~h}$ (Chinma and Igyor, 2007). The dried materials obtained were ground with a laboratory crusher (Culatti, France) equipped with a $10 \mu \mathrm{m}$ mesh sieve. The dried powdered samples obtained were stored in polythene bags at $4{ }^{\circ} \mathrm{C}$ until further analyses.

\section{Analysis}

\section{Physicochemical composition}

Moisture, matter dry, ash, $\mathrm{pH}$, proteins, lipids and titratable acidity were determined by AOAC method (AOAC, 1990). Total fiber content was determined using Weende method (Wolf, 1968). The amount of carbohydrates was determined by difference as follows:

$\%$ Carbohydrates $=100-(\%$ moisture $+\%$ proteins $+\%$ lipids $+\%$ ash $+\%$ fiber). Total sugar was determined by Dubois et al. (1956). The amount of reducing sugars was estimated by the method of Bernfeld (1955).

\section{Minerals}

Mineral content was estimated by dry ashing of dried powdered sample $(5 \mathrm{~g})$ in a 
muffle furnace (Pyrolabo, France). Ash obtained was dissolved in $5 \mathrm{~mL}$ of $\mathrm{HCl} / \mathrm{HNO}_{3}$ and analyzed using the atomic absorption spectrophotometer (AAS model, SP9).

The studied mineral were calcium $(424.7 \mathrm{~nm}), \quad$ magnesium $(285.2 \mathrm{~nm})$, phosphorus $(178.2 \mathrm{~nm})$, potassium $(766.5$ $\mathrm{nm})$, sodium $(589.6 \mathrm{~nm})$, iron $(248.3 \mathrm{~nm})$, copper $(324.8 \mathrm{~nm}), \quad$ zinc $(213.9 \mathrm{~nm})$, manganese $(279.5 \mathrm{~nm})$, cobalt $(240.7 \mathrm{~nm})$.

Selenium content was determined by inductively coupled plasma optical emission spectroscopy (ICP-OES Optima 2100DV, Perkin Elmer) at $196.1 \mathrm{~nm}$. A mass of 0.1452 $\mathrm{g}$ was weighed and digested with $20 \mathrm{ml}$ of nitric acid (7M) in an autoclave at $102{ }^{\circ} \mathrm{C}$ for 3 hours. After digestion, the sample was filtered and filled to $100 \mathrm{ml}$ before analysis.

\section{Vitamins and Carotenoids}

Quantitative determination of Bgroup vitamins $\left(\mathrm{B}_{1} ; \mathrm{B}_{2} ; \mathrm{B}_{6} ; \mathrm{B}_{9}\right.$ and $\left.\mathrm{B}_{12}\right)$ was performed by reversed-phase highperformance liquid chromatography (RPHPLC). In brief, Justicia galeopsis powder (1 g) was placed into a $100 \mathrm{~mL}$ volumetric flask, dissolved in $50 \mathrm{~mL}$ of dilution solvent (mixture of $25 \mathrm{~mL}$ of sodium carbonate solvent $+475 \mathrm{~mL}$ of mobile phase) and kept in an ultrasonic bath during $10 \mathrm{~min}$. Then, the contents were cooled and taken to volume with the same dilution solvent. The mixture was through a micropore filter $(0.45 \mu \mathrm{m})$. Ten milliliters were withdrawn in a $20 \mathrm{~mL}$ volumetric flask and diluted to volume with mobile phase. Twenty microliters of the filtrate were injected into the HPLC system. Quantification of vitamin B content was accomplished by comparison to vitamin B standards.

Standard stock solutions for thiamine, riboflavin, pyridoxine, folate and cobalamin were prepared as reported previously
(Ringling and Rychlik, 2013). The method used a Hypersil C8 $(250$ x $4.6 \mathrm{~mm}, 5 \mu \mathrm{m})$ column, under the following chromatographic conditions: gradient elution, using a mobile phase composed by $880 \mathrm{~mL}$ of potassium phosphate buffer ( $\mathrm{pH} 2.65)$ and $120 \mathrm{~mL}$ of methanol as an organic modifier. The mobile phase was delivered at a flow rate of 1 $\mathrm{mL} / \mathrm{min}$ and the detection was made at 280 $\mathrm{nm}$. The amount of vitamin $\mathrm{C}$ in analyzed samples was determined by titration using the method described by Pongracz et al. (1995). About $10 \mathrm{~g}$ of ground fresh leaves were soaked for $10 \mathrm{~min}$ in $40 \mathrm{~mL}$ metaphosphoric acid-acetic acid $(2 \%, w / v)$. The mixture was centrifuged at $3000 \mathrm{rpm}$ for $20 \mathrm{~min}$ and the supernatant obtained was diluted and adjusted with $50 \mathrm{~mL}$ of bi-distilled water. Ten (10) $\mathrm{mL}$ of this mixture was titrated with dichlorophenol-indophenol (DCPIP) $0.5 \mathrm{~g} / \mathrm{L}$. Carotenoids content was carried out according to Rodriguez-Amaya (2001). Two (2) g of ground fresh leaves were mixed three times with $50 \mathrm{~mL}$ of acetone until loss of pigmentation. The mixture obtained was filtered through Whatman No. 4 filter paper and total carotenoids were extracted with 100 $\mathrm{mL}$ of petroleum ether. Absorbance of extracted fraction was then read at $450 \mathrm{~nm}$ by using a spectrophotometer (PG Instruments, England). Total carotenoids content was subsequently estimated using a calibration curve of $\beta$-carotene $(1 \mathrm{mg} / \mathrm{mL})$ as standard.

\section{Oxalates, phytates and tannins quantification}

Oxalates content was performed using a titration method (Day and Underwood, 1986). One (1) $g$ of dried powdered sample was weighed into $100 \mathrm{~mL}$ conical flask. A quantity of $75 \mathrm{~mL}$ of sulphuric acid (3 M) was added and stirred for $1 \mathrm{~h}$ with a magnetic stirrer. The mixture was filtered and $25 \mathrm{~mL}$ of 
the filtrate was titrated while hot with $\mathrm{KMnO}_{4}$ solution $(0.05 \mathrm{M})$ until an extremely faint pale pink color persisted for 15-30 sec. Phytates content was determined using the Wade's reagent colorimetric method (Latta and Eskin, 1980). A quantity (1g) of dried powdered sample was mixed with $20 \mathrm{~mL}$ of hydrochloric acid $(0.65 \mathrm{~N})$ and stirred for $12 \mathrm{~h}$ with a magnetic Stirrer. The mixture was centrifuged at $12000 \mathrm{rpm}$ for $40 \mathrm{~min}$. An aliquot $(0.5 \mathrm{~mL})$ of supernatant was added with $3 \mathrm{~mL}$ of Wade's reagent. The reaction mixture was incubated for $15 \mathrm{~min}$ and absorbance was measured at $490 \mathrm{~nm}$ by using a spectrophotometer (PG Instruments, England). Phytates content was estimated using a calibration curve of sodium phytate (10 $\mathrm{mg} / \mathrm{mL}$ ) as standard. Tannin content was determined using the method described by Broadhurst and Jones (1978) and was expressed as the equivalent of tannic acid.

\section{Determination of molar ratio of antinutrients to minerals}

The molar ratio between antinutrient and mineral was obtained using the formula (1) describes by Woldegiorgis et al. (2015). Molar ratio $=[$ Moles of antinutrient $] /$ [Moles of mineral $]=[\mathrm{mg}$ antinutrient $/ \mathrm{MW}$ of antinutrient] / [mg mineral/MW of mineral]. Where $\mathrm{MW}=$ atomic weight. (1)

\section{Data analysis}

All the analyses were performed in triplicate and data were analyzed using EXCELL and STATISTICA 7.1 (StatSoft). The values were expressed in the form of the mean \pm standard deviation (SD).

\section{RESULTS}

\section{Physicochemical properties}

The physicochemical properties of Justicia galeopsis leaves examined in this study were presented in Table 1 and based on dry matter. The leaves of $J$. galeopsis had a $\mathrm{pH}$ of $7.33 \pm 0.08$ and a titratable acidity of $5.66 \pm 0.57 \mathrm{meq} / 100 \mathrm{~g}$. The leaves' ash content was $17.76 \pm 1.18 \%$. Lipid and protein contents were respectively $4.06 \pm 0.70 \%$ and $21.11 \pm 0.03 \%$. Reducing sugars and total sugars, their rates were respectively $0.14 \pm$ 0.00 and $0.90 \pm 0.00 \%$. The crude fibers were about $33.86 \pm 0.43 \%$.

\section{Minerals composition}

The mineral contents of the leaves of Justicia galeopsis on dry matter basis were shown in Table 2 . They contained very high levels of macroelements including potassium $(103.08 \pm 0.64 \mathrm{~g} / \mathrm{kg})$, phosphorus (77.66 \pm $0.46 \mathrm{~g} / \mathrm{kg})$, calcium $(59.87 \pm 0.32 \mathrm{~g} / \mathrm{kg})$, and sodium $(28.30 \pm 0.46 \mathrm{~g} / \mathrm{kg})$. The lowest macronutrient content was magnesium $(\mathrm{Mg})$ with $3.52 \pm 0.02 \mathrm{~g} / \mathrm{kg}$. The leaves were also rich in trace elements including iron (373.01 \pm $10.83 \mathrm{mg} / \mathrm{kg})$, zinc $(177.84 \pm 15.81 \mathrm{mg} / \mathrm{kg})$, manganese $(128.57 \pm 8.36 \mathrm{mg} / \mathrm{kg})$ and copper $(16.32 \pm 1.40 \mathrm{mg} / \mathrm{kg})$. The results also showed low levels of cobalt $(0.23 \pm 0.03 \mathrm{mg} / \mathrm{kg})$ and selenium $(<0.01 \pm 0.01 \mathrm{mg} / \mathrm{kg})$.

\section{Vitamins composition and carotenoids}

Vitamins and carotenoids compositions were indicated in Table 3. The leaves of Justicia galeopsis had a vitamin B12 rate of $4173.09 \pm 15.27 \mathrm{mg} / \mathrm{kg}$ DM. Vitamin $\mathrm{C}$ and carotenoid contents were respectively $892.17 \pm 1.13 \mathrm{mg} / \mathrm{kg}$ and $38.1 \pm 0.08 \mathrm{mg} / \mathrm{kg}$ of fresh matter. The rate of vitamin B9 in the leaves was $8.77 \pm 0.18 \mathrm{mg} / \mathrm{kg}$ DM. Vitamin B2 rate was $5.57 \pm 0.47 \mathrm{mg} / \mathrm{kg} \mathrm{DM}$ while vitamin B1 rate was $1.94 \pm 0.06 \mathrm{mg} / \mathrm{kg}$ DM.

\section{Antinutrients quantification and molar} ratios of antinutrients and minerals

The results of oxalates, phytates and tannin quantification of Justicia galeopsis 
leaves based on dry matter were presented in Table 4. Oxalate was the most abundant antinutritive factor $(740.67 \pm 12.70 \mathrm{mg} / 100 \mathrm{~g})$ in the leaves followed by tannin $(66.33 \pm 2.31$ $\mathrm{mg} / 100 \mathrm{~g})$ and then Phytate $(33.83 \pm 2.45$ $\mathrm{mg} / 100 \mathrm{~g})$. The molar ratios between antinutrients and minerals of $J$. galeopsis leaves were showed in Table 5. The results indicated that molar ratio of $[$ Phytate]/[Fe], [Phytate]/[Zn], [Phytate]/[Ca], [Ca][Phytate]/[Zn], [Oxalate]/[Ca] and $[$ Oxalate $] /[(\mathrm{Ca}+\mathrm{Mg})]$ for $J$. galeopsis leaves were $0.11,0.15,0.00,0.28,0.05$ and 0.07 respectively. These molar ratios were low compared with their corresponding critical value.

Table 1: Physicochemical properties of Justicia galepsis leaves (\% of dry matters).

\begin{tabular}{lc}
\hline Parameters & Justicia galepsis leaves \\
\hline Moisture $(\%)$ & $18.05 \pm 0.07$ \\
\hline $\mathrm{pH}$ & $7.33 \pm 0.08$ \\
\hline Titratable acidity $(\mathrm{meq} / 100 \mathrm{~g})$ & $5.66 \pm 0.57$ \\
\hline Ash $(\%)$ & $17.76 \pm 1.18$ \\
\hline Crude fibers $(\%)$ & $33.86 \pm 0.43$ \\
\hline Lipids $(\%)$ & $4.06 \pm 0.70$ \\
\hline Proteins $(\%)$ & $21.11 \pm 0.03$ \\
\hline Carbohydrates $(\%)$ & $23.21 \pm 0.00$ \\
\hline Total sugar $(\%)$ & $0.90 \pm 0.00$ \\
\hline Reducing sugars $(\%)$ & $0.14 \pm 0.00$
\end{tabular}

Table 2: Mineral composition of Justicia galepsis leaves.

\begin{tabular}{lc}
\hline Minerals & Justicia galepsis leaves \\
\hline Macro elements $(\mathbf{g} / \mathbf{k g})$ & $59.87 \pm 0.32$ \\
\hline Calcium $(\mathrm{Ca})$ & $3.52 \pm 0.02$ \\
\hline Magnesium $(\mathrm{Mg})$ & $77.66 \pm 0.46$ \\
\hline Phosphorus $(\mathrm{P})$ & $103.08 \pm 0.64$ \\
\hline Potassium $(\mathrm{K})$ & $28.30 \pm 0.46$ \\
\hline Sodium $(\mathrm{Na})$ & \\
\hline Oligoelements $(\mathbf{m g} / \mathbf{k g})$ & $0.23 \pm 0.03$ \\
\hline Cobalt $(\mathrm{Co})$ & $16.32 \pm 1.40$ \\
\hline Copper $(\mathrm{Cu})$ & $373.01 \pm 10.83$ \\
\hline iron $(\mathrm{Fe})$ & $128.57 \pm 8.36$ \\
\hline Manganese $(\mathrm{Mn})$ & $<0.01 \pm 0.01$ \\
\hline Selenium $(\mathrm{Se})$ & $177.84 \pm 15.81$ \\
\hline Zinc $(\mathrm{Zn})$ &
\end{tabular}


Table 3: Vitamins and carotenoids composition of Justicia galeopsis leaves.

\begin{tabular}{lc}
\hline Parameters $(\mathbf{m g} / \mathbf{k g}$ of $\mathbf{D M})$ & Justicia galepsis leaves \\
\hline Carotenoids $(\mathrm{mg} / \mathrm{kg} \mathrm{FM})$ & $38.1 \pm 0.08$ \\
\hline Vitamin $\mathrm{B}_{1}$ & $1.94 \pm 0.06$ \\
\hline Vitamin $\mathrm{B}_{12}$ & $4173.09 \pm 15.27$ \\
\hline Vitamin $\mathrm{B}_{2}$ & $5.57 \pm 0.47$ \\
\hline Vitamin $\mathrm{B}_{6}$ & $\mathrm{ND}$ \\
\hline Vitamin $\mathrm{B}_{9}$ & $8.77 \pm 0.18$ \\
\hline Vitamin $\mathrm{C}(\mathrm{mg} / \mathrm{kg}$ of $\mathrm{FM})$ & $892.17 \pm 1.13$ \\
\hline
\end{tabular}

Data are represented as means \pm SD $(n=3)$. DM: Dry Matter; FM: Fresh matter; ND: Not detected

Table 4: Antinutritional factors content of Justicia galeopsis leaves.

\begin{tabular}{lc}
\hline Parameters (mg/100 g of DM) & Justicia galepsis leaves \\
\hline Phytate & $33.83 \pm 2.45$ \\
\hline Oxalate & $740.67 \pm 12.70$ \\
\hline Tannin $(\mathrm{mg} \mathrm{EC} / 100 \mathrm{~g})$ & $66.33 \pm 2.31$ \\
\hline
\end{tabular}

Data are represented as means \pm SD $(n=3)$. DM: Dry Matter

Table 5: Molar ratio between phytate and minerals, Oxalate and minerals.

\begin{tabular}{lcc}
\hline Antinutrient/mineral ratio & Value & Critical value* \\
\hline$[$ Phytate $] /[\mathrm{Fe}]$ & 0.11 & 0.4 \\
\hline$[$ Phytate $] /[\mathrm{Zn}]$ & 0.15 & $<1.5$ \\
\hline$[$ Phytate $] /[\mathrm{Ca}$ & 0.00 & 0.5 \\
\hline$[$ Ca $][$ Phytate $] /[\mathrm{Zn}]$ & 0.28 & $<0.5$ \\
\hline$[$ Oxalate $] /[\mathrm{Ca}]$ & 0.05 & 2.5 \\
\hline$[$ Oxalate $] /[\mathrm{Ca}+\mathrm{Mg})]$ & 0.07 & 2.5 \\
\hline
\end{tabular}

Values are expressed as mean \pm standard deviation, SD (n=3). *Source: Hassan et al. (2007), Frontela et al. (2008), Obah and Amusan (2009).

\section{DISCUSSION}

Physicochemical properties of Justicia galeopsis leaves have showed high content of crude fiber, followed by protein and ash content. The amount of fiber $(33.86 \%)$ in the studied leaves was greater than those of $S$. monostachyus, a green leafy vegetable in Nigeria (12.90\%) mentioned by Afolabi et al. (2012). Its consumption could therefore help the proper functioning of the digestive system, reduce the risk of hypertension, constipation, diabetes, colon cancer. J. galeopsis leaves are a good source of protein $(21.11 \%)$. They could therefore contribute to ensuring food security for the population. This value of protein was higher than that found by Obichi et al. (2015) for $S$. monostachyus leaves $(10.11 \%)$. The lipid content of J. galeopsis leaves was relatively low $(4.06 \%)$. The low value of fat recorded showed that $J$. galeopsis can be recommended as weight reducing diet since low fat food 
reduces the level of cholesterol and obesity (Gordon and kessel, 2002). They can therefore be consumed in abundance and safely without risk of cardiovascular disease, obesity and other related diseases. This value is like fat percentage reported in $S$. monostachyus (Afolabi et al., 2012) which are about $4.64 \%$. According to Afolabi et al. (2012), these leaves would be a good source of fat-soluble vitamins.

Mineral analysis revealed that leaves of J. galeopsis contained a high rate of potassium phosphorus, calcium, sodium, iron, zinc and manganese. They are a good source of minerals. They can therefore be recommended for infants, pregnant women and the elderly, to cover mineral needs. In fact, the consumption of $16.73 \mathrm{~g}, 114.29 \mathrm{~g}$, $21.45 \mathrm{~g}$ and $33.75 \mathrm{~g}$ of these fresh leaves could cover respectively the recommended daily doses for an adult in calcium (1000 $\mathrm{mg}$ /day), magnesium (400 mg/day), iron (8 $\mathrm{mg}$ /day) and zinc (6 mg/day) mentioned by Huskisson et al. (2007). The values found for potassium and calcium are high compared with those reported by Acho et al. (2014) for Basella alba leaves which were, respectively $28.93 \mathrm{~g} / \mathrm{kg}$ and $41.37 \mathrm{~g} / \mathrm{kg}$ and Anin-Atchibri et al. (2012) for Solanum nigrum leaves (49.85 mg/kg, potassium; $15.090 \mathrm{mg} / \mathrm{kg}$, calcium). The consumption of $J$. galeopsis leaves would provide much more potassium and calcium than $S$. nigrum and B. alba.

Vitamin B12 content of Justicia galeopsis leaves was high, followed by vitamin C, carotenoids, vitamin B9 and vitamin B2. Vitamin B1 content was low. The consumption of only $134.5 \mathrm{~g}$ of leaves could significantly help pregnant women cover their needs which are $120 \mathrm{mg} /$ day for vitamin $\mathrm{C}$ and $2.6 \mu \mathrm{g} /$ day for vitamin B12 (Schlienger, 2014) and protect them. J. galeopsis vitamin C levels is greater than that of $S$. monostachyus leaves $(420 \mathrm{mg} / \mathrm{kg})$ mentioned by Obichi et al. (2015), Basella alba (700 $\mathrm{mg} / \mathrm{kg}$ ) and Corchorus olitorius $(700 \mathrm{mg} / \mathrm{kg}$ ) studied by Acho et al. (2014). The consumption of $J$. galeopsis leaves could reduce iron deficiency which is the most common nutritional disorder. Indeed, thanks of it high content in vitamin $\mathrm{C}$, iron present in $J$. galeopsis leaves may be available. According to Thompson (2011), a meal containing many inhibitors of iron absorption should preferably contain at least $25 \mathrm{mg}$ of ascorbic acid and possibly more to significantly boost absorption of non-heme iron.

Carotenoids are considered sources of provitamin A in plants. Their daily dose is between 3.6 and $4.8 \mathrm{mg} /$ day. The carotenoid contents of $J$. galeopsis leaves were 46.49 $\mathrm{mg} / \mathrm{kg}$. Therefore, a consumption of about 105 $\mathrm{g}$ of leaves would cover the needs and fight against vitamin deficiency. J. galeopsis leaves are very nutritious. Indeed, consumption of their leaves brings important and sufficient rate of vitamins and minerals necessary for the human body.

The phytate content of J. galeopsis (740.67 $\pm 12.70 \mathrm{mg} / 100 \mathrm{~g}$ dry weight) was similar to that reported for Melocia corchorifolia leaves which is $788.57 \pm 18.63$ $\mathrm{mg} / 100 \mathrm{~g}$ DW (Hassan et al., 2011). Acho et al. (2014) reported low rate of phytate in some leafy vegetables such as Basella alba, Colocasia esculenta and Corchorus olitorius as respectively $19,78 \mathrm{mg} / 100 \mathrm{~g}, 26,27 \mathrm{mg} / 100$ $\mathrm{g}$ and $38,75 \mathrm{mg} / 100 \mathrm{~g}$ wet weight. These contents were equivalent to $194.30 \mathrm{mg} / 100 \mathrm{~g}$, $148.84 \mathrm{mg} / 100 \mathrm{~g}$ and $246.50 \mathrm{mg} / 100 \mathrm{~g}$ dry weight. Phytate content in the leaves of $J$. galeopsis was less than $0.04 \%$ reported in food items (Adeduntan and Oyeride, 2009). Phytate is known to decrease the bioavailability of minerals, especially 
calcium, magnesium, iron and zinc (Bhandari and Kawabata, 2004). Hurrel (2004) reported that a phytic acid intake of 4-9 mg/100 g dry matter decreases iron absorption by $4-5$ folds in human. To predict the effect of phytate on the bioavailability of iron, zinc and calcium, phytate to nutrients ratios were calculated. The calculated molar ratios of phytate to iron, zinc and calcium of $J$. galeopsis were below the critical level of $0.4,1.5$ and 0.5 respectively as outline by Frontela et al. (2008) and Hassan et al. (2011). This result means that absorption of iron, zinc and calcium was not adversely affected by phytate. It's not the case of $C$. olitorius and $S$. melongena whose [phytates]/ [Fe] molar ratios were above the critical level of 0.4 (Acho et al. 2014) indicating that the phytates of these leafy vegetables may hinder iron bioavailability (Umar et al., 2007).

The analyzed $J$. galeopsis leaves have total oxalate content of $740.67 \pm 12.70$ $\mathrm{mg} / 100 \mathrm{~g}$ dry matter which is low compared with those reported by Acho et al. (2014) in the leaves of $B$. alba $(650 \mathrm{mg} / 100 \mathrm{~g}), C$. esculenta $(580 \mathrm{mg} / 100 \mathrm{~g})$ and C. olitorius $(780$ $\mathrm{mg} / 100 \mathrm{~g}$ ) when there are expressed in dry weight $(6385 \mathrm{mg} / 100 \mathrm{~g}, 3286 \mathrm{mg} / 100 \mathrm{~g}$ and $4961 \mathrm{mg} / 100 \mathrm{~g}$, respectively). From the result, it was observed that in $J$. galeopsis [oxalate] $/[\mathrm{Ca}]$ ratio $(0.05)$ and [oxalate]/[(Ca+Mg)] ratio (0.07) are below the critical level of 2.5 known to impair calcium bioavailability (Umar et al., 2007). The present of oxalate in J. galeopsis leaves don't affect the bioavailability of calcium.

\section{Conclusion}

This study has revealed that Justicia galeopsis leaves consumed in Côte d'Ivoire could help to cover the nutritional needs of the populations. They are very rich in fibers, proteins, minerals and vitamins. The minerals analysis of $J$. galeopsis leaves indicated that it is rich in most mineral elements with high predicted bioavailability for iron, calcium, zinc and magnesium. Mineral and vitamin contents of these leaves are enough to satisfy the recommended dietary allowances of theses micronutrients. The leaves of J. galeopsis can be considered as an alternative source of energy and nutrients that are important to prevent malnutrition and deficiency diseases in developing countries. The consumption of this plant could therefore provide several health benefits. As a spontaneous food plant, this plant deserves to be popularized. Thus, it could contribute to populations' food security.

\section{COMPETING INTERESTS}

The authors declare that they have no competing interests.

\section{AUTHORS' CONTRIBUTIONS}

ALL is the main investigator of the research; she wrote the experimental protocol and the first draft of the manuscript. KYBA contributed to write the experimental protocol and the first draft. KHK developed the protocol, collected the data. KB has improved the versions of the manuscript and he monitored the group for all research. All authors have read and approved the final version of the manuscript.

\section{ACKNOWLEDGMENTS}

The authors thank technician of the national floristic center Mr. Yapo ASSI Jean for authentication and identification of Justicia galeopsis leaf.

\section{REFERENCES}

Acho CF, Zoue LT, Akpa EE, Yapo VG, Niamke SL. 2014. Leafy vegetables consumed in Southern Côte d'Ivoire: a 
source of high value nutrients. J. Anim. Plant Sci., 20(3): 3159-3170.

Adeduntan SA, Oyerinde AS. 2009. Evaluation of chemical and antinutritional characteristics of obeche (Triplochition scleroxylon) and some mulberry (Morus alba) leaves. Int. J. Biol. Chem. Sci., 3(4): 681-687. DOI: http://dx.doi.org/10.4314/ijbcs.v3i4.4717 7

Afolabi IS, Akpokene ON, Fashola DV, Famakin TC. 2012. Comparative evaluation of the nutritional benefits of some underutilised plants leaves. J. Nat. Prod. Plant Resour., 2(2): 261-266.

Aka N, Bamba SB, Soro G, Soro N. 2013. Etude hydrochimique et microbiologique des nappes d'altérites sous climat tropical humide : cas du département d'Abengourou (Sud-Est de la Côte d'Ivoire). Larhyss J., 16: 31-52. DOI : http://larhyss.net/ojs/index.php/larhyss/ar ticle/view/179/169

Anin-Atchibri ALO, Soro LC, Kouamé C, Agbo EA, Kouadio KKA. 2012. Valeur nutritionnelle des légumes feuilles consommés en Côte d'Ivoire. Int. J. Biol. Chem. Sci., 6(1): 128-135. DOI: http://dx.doi.org/10.4314/ijbcs.v6i1.12

AOAC. 1990. Official methods of analysis of the Association of Official Analytical Chemists (15th edn). Association of Official Analytical Chemists: Washington.

Broadhurst RB, Jones WT. 1978. Analysis of condensed tannins using acidified vanillin. J. Food Sci. Agric., 29(9): 788794.

DOI: https://doi.org/10.1002/jsfa.2740290908

Betti JL, Ngankoué CM, Dibong SD, Singa AE. 2016. Etude ethnobotanique des plantes alimentaires spontanées vendues dans les marchés de Yaoundé,
Cameroun. Int. J. Biol. Chem. Sci., 10(4): $\quad 1678-1693 . \quad$ DOI : http://dx.doi.org/10.4314/ijbcs.v10i4.19 Bhandari MR, Kawabata J. 2004. Assessment of antinutritional factors and bioavailability of calcium and zinc in wild yam (Dioscorea spp.) tubers of Nepal. Food Chem., 85: 281-287. DOI: https://doi.org/10.1016/j.foodchem.2003. 07.006

Bernfeld P. 1955. Amylase $\alpha$ and $\beta$. Method in Enzymology i.s.p colowich and N.O. Kaplan (9th edn). Academic Inc: New York.

Chinma CE, Igyor MA. 2007. Micronutrients and anti-nutritional content of select tropical vegetables grown in south-east, Nigeria. Nig. Food J., 25: 111-115. DOI: http://dx.doi.org/10.4314/nifoj.v25i1.336 59

Day RA, Underwood AL. 1986. Quantitative Analysis (5th edn). Prentice Hall: New Jersey.

Djaha AJB, Gnahoua GM. 2014. Contribution à l'inventaire et à la domestication des espèces alimentaires sauvages de Côte d'Ivoire: Cas des Départements d'Agboville et d'Oumé. J. Appl. Biosci., 78: $\quad 6620-6629 . \quad$ DOI: http://dx.doi.org/10.4314/jab.v78i1.8

Dubois M, Gilles K, Hamilton J, Rebers P, Smith F. 1956. Colorimetric methods for determination of sugars and related substances. Anal. Chem., 28: 350-356. DOI: 10.1021/ac60111a017

Frontela C, García-Alonso FJ, Ros G, Martínez C. 2008. Phytic acid and inositol phosphates in raw flours and infant cereals: The effect of processing. J. Food Compos. Anal., 21: 343-350. DOI: https://doi.org/10.1016/j.jfca.2008.02.00 3 
Gordon MN, kessel MN. 2002. Perspective in Nutrition (5th edn). McGraw Hill Company: New York.

Hassan LG, Umar KJ, Umar Z. 2007. Antinutritive factors in Tribulus terrestris (Linn) leaves and predicted calcium and zinc bioavailability. J. Trop. Biosci., 7: 33-36.

Hassan LG, Umar KJ, Dangoggo SM, Maigandi AS. 2011. Anti-nutrient Composition and Bioavailability Prediction as Exemplified by Calcium, Iron and Zinc in Melocia corchorifolia Leaves. Pak. J. Nutr., 10(1): 23-28. DOI: 10.3923/pjn.2011.23.28

Huskisson E, Maggini S, RUF M. 2007. The Role of vitamins and minerals in energy metabolism and well-being. J. Int. Med. Res., 35: 277-289. DOI: https://doi.org/10.1177/14732300070350 0301

Hurrel RF. 2004. Phytic acid degradation as a means of improving iron absorption. Int. J. Vitam. Nutr. Res., 74: 445-52. DOI: https://doi.org/10.1024/03009831.74.6.445.

Idoko O, Emmanuel SA, Aguzue OC, Akandji FT, Thomas SA, Osuagwu I. 2014. Phytochemical screening, proximate analysis and mineral composition of some leafy vegetables consumed in Nigeria. Int. J. Adv. Chem., 2(2):175177. DOI: $10.14419 /$ ijac.v2i2.3514

Kouakou KH. 2015. Etude de consommation et valeur nutritionnelle d'une plante spontanée, Solenostemon monostachyus (P. Beauv) Briq., dans le département d'Abengourou. Mémoire de master, Université Nangui Abrogoua, Abidjan, p.61.

Kouamé NMT, Gnahoua GM, Kouassi KE, Traoré D. 2008. Plantes alimentaires spontanées de la région du Fromager
(Centre-Ouest de la Côte d'Ivoire): flore, habitats et organes consommés. Sci. Nat., 5(1): $\quad 61-70 . \quad$ DOI: http://dx.doi.org/10.4314/scinat.v5i1.421 52

Latta M, Eskin M. 1980. A simple method for phytate determination. J. Agric. Food Chem., 28: 1313-1315. DOI: http://dx.doi.org/10.1021/jf60232a049

Loukou AL, Kouakou KH, Agbo AE, Brou K. 2018. Consumption survey of Justicia galeopsis T. Anderson Ex C.B. Clarke (Acanthaceae) a wild food plant in Côte d'Ivoire (West Africa). Eur. Sci. J., 14(21): 361-371. DOI: http://dx.doi.org/10.19044/esj.2018.v14n $21 \mathrm{p} 361$

Mohammed AM, Wolf W, Spie WEL. 2002. Physical, morphological and chemical characteristics, oil recovery and fatty acid composition of Balanites aegyptiaca Del. Kernels. Plant Foods Human Nutr., 57: 179-189. DOI: https://doi.org/10.1023/A:101523761201 8

Obah G, Amusan TV. 2009. Nutritive value and antioxidant properties of cereal gruels produced from fermented maize and sorghum. Food Biotechnol., 23: 1731.

DOI:

https://doi.org/10.1080/08905430802671 899

Obichi EA, Monago CC, Belonwu DC. 2015. Nutritional Qualities and Phytochemical Compositions of Solenostemon monostachyus (Family Lamiaceae). $J$. Environ. Earth Sci., 5(3): 105-111.

Pongracz G, Weiser H, Matzinger D. 1995. Tocopherole - Antioxidantien der Natur. Eur. J. Lipid Sci. Technol., 97: 90-104. DOI:

https://doi.org/10.1002/lipi.19950970303 
Ringling C, Rychlik M. 2013. Analysis of seven folates in food by LC-MS/MS to improve accuracy of total folate data. Eur Food Res Technol., 236: 17-28. DOI: 10.1007/s00217-012-1849-x

Rodriguez-Amaya DB. 2001. A guide to Carotenoids Analysis in Foods. ILSI Press: Washington DC.

Schlienger JL. 2014 Besoins nutritionnels et apports conseilles : adultes, femmes enceintes, personnes âgées, sportifs. In Nutrition clinique pratique. Elsevier Masson (ed). Elsevier Masson SAS : Paris ; 43-56.

Thompson B. 2011. Combating Iron Deficiency: Food-based Approaches. In Combating Micronutrient Deficiencies: Food-based Approaches, Thompson B, Amoroso L (eds). FAO: Rome; 268-288.
Umar KJ, Hassan LG, Dangoggo SM, Inuwa M, Amustapha MN. 2007. Nutritional content of Melochia corchorifolia Linn leaves. Int. J. Biol. Chem. Sci., 1: 250255. DOI: $10.3923 / \mathrm{ijbc} .2007 .250 .255$

Woldegiorgis AZ, Abate D, Haki GD, Ziegler GR. 2015. Major, minor and toxic minerals and anti-nutrients composition in edible mushrooms collected from Ethiopia. J Food Process Technol., 6(3): 430-437. DOI: $10.4172 / 2157-$ 7110.1000430

Wolf JP. 1968. Manuel d'Analyse des Corps Gras. Azoulay : Paris.

Yao K, Koné MW, Bonfoh B, Kamanzi K. 2014. Antioxidant activity and total phenolic content of nine plants from Côte d'Ivoire (West Africa). J. Appl. Pharm. Sci., 4(8): 036-041. DOI: 10.7324/JAPS.2014.40807 